\title{
Stability of Encapsulated Lactobacillus reuteri during Harsh Conditions, Storage Period, and Simulated In Vitro Conditions
}

\author{
Abdolazim Soltani Lak (iD, ${ }^{1}$ Mohammad Hossein Marhamatizadeh $\left(\mathbb{D},{ }^{1}\right.$ \\ and Hossein Fattahi ${ }^{2}$ \\ ${ }^{1}$ Department of Food Hygiene, Faculty of Veterinary Medicine, Kazeroon Branch, Islamic Azad University, Kazeroon, Iran \\ ${ }^{2}$ Department of Microbiology, Faculty of Veterinary Medicine, Kazeroon Branch, Islamic Azad University, Kazeroon, Iran \\ Correspondence should be addressed to Mohammad Hossein Marhamatizadeh; drmarhamati@gmail.com
}

Received 7 May 2021; Revised 25 June 2021; Accepted 15 October 2021; Published 23 October 2021

Academic Editor: Muhammad Imran

Copyright ( 2021 Abdolazim Soltani Lak et al. This is an open access article distributed under the Creative Commons Attribution License, which permits unrestricted use, distribution, and reproduction in any medium, provided the original work is properly cited.

\begin{abstract}
Viability of probiotics in the foods and human bodies is important, because a certain minimum count of bacteria is necessary to impose health promoting effects. In the present work, we encapsulated Lactobacillus reuteri within whey protein isolate (WPI), soy protein isolate (SPI), WPI + inulin (WPI4I), and SPI + inulin (SPI4I) through spray drying method and investigated the efficiency of the microcapsules on the protection of the cells under different conditions (heat, salt, bile salt, penicillin, $\mathrm{pH}$, simulated gastrointestinal condition, and storage). The particle size of the samples was in the range of 195.2-358.1 nm. The sensitivity of unencapsulated bacteria to heat was considerably higher than that to the encapsulated bacteria, so that, at $80^{\circ} \mathrm{C}$, no growth (of unencapsulated type) was observed. At $60^{\circ} \mathrm{C}$ and $40^{\circ} \mathrm{C}$, the cell count of free bacteria decreased to 5.81 and $8.04 \log \mathrm{CFU} / \mathrm{mL}$, respectively. The bacteria encapsulated within SPI4I showed the highest viability at these temperatures. A comparison between the effects of different $\mathrm{pH}$ values showed $\mathrm{pH} 1.5$ more lethal than 2.5 and 7 . The effect of $\mathrm{NaCl}$ at $4 \%$ concentration on decreasing the bacterial count was more notable than $2 \%$. However, the used wall materials in all conditions resulted in higher viability of the cells compared to the free cells. Among different types of wall materials, it was observed that WPI4I imposed the best protective effect. The higher viability of cells within WPI4I wall material was also observed during the storage time. The viability of encapsulated cells decreased from 10.35 to $10.40 \log \mathrm{CFU} / \mathrm{g}$ in the first week and to 8.93-9.23 log CFU/g in the last week of storage.
\end{abstract}

\section{Introduction}

Probiotic foods are a kind of functional foods containing living microorganisms (M.Os) that can induce health beneficial effects on human $[1,2]$. Based on the report of FAO and WHO, the minimum count of live probiotic M.Os in the foods to be effective on health status is $10^{6}-10^{7} \mathrm{CFU}$ per $\mathrm{g}[3]$. These M.Os should reach their appropriate site of operation in the gastrointestinal track (GI) to efficiently apply their positive impacts; however, their survival in the GI and against food processing (especially about Lactobacilli strains) is low [4-6].

Scientists are looking for methods to enhance the viability of probiotic M.Os in an adequate count in the food products and during processing conditions until reaching human body. Using the probiotics in microcapsules, which can protect them against harsh conditions, is among the proposed methods [7-9]. There are reports on survival of probiotic M.Os in a protected state in temperature range of $40-65^{\circ} \mathrm{C}[10,11]$. In the present work, the viability of the probiotic M.O, Lactobacillus reuteri, in the free and encapsulated (within different wall materials) forms was investigated against heat treatment, acidic $\mathrm{pH}$, and high salt concentration, as well as in the presence of chemical substances and during the storage period.

\section{Material and Methods}

2.1. Material. WPI and SPI were bought from Hilmar (USA), and inulin was purchased from Sensus (Lawrenceville, NJ, USA). $\mathrm{LiCl}, \mathrm{NaCl}, \mathrm{HCl}, \mathrm{NaOH}$, Lactobacilli de Man 
Rogosa Sharpe medium (MRS), Muller Hinton medium, and agar-agar were obtained from Merck (Merck, Darmstadt, Germany). Pepsin, pancreatin, and bile salts were purchased from Sigma-Aldrich (Sigma Chemical Co., St. Louis, MO, USA). Penicillin G was purchased from Dana pharmacy (Dana pharmacy Co., Tehran, Iran). Remarkably, the water used in the present study was double distilled deionized (DDW).

2.2. Preparing Probiotic M.Os. The probiotic strain used in this study was Lactobacillus reuteri (L. reuteri). One colony of the mentioned M.O was moved into MRS broth $(10 \mathrm{~mL})$ and kept constant for $18 \mathrm{~h}$ at $37^{\circ} \mathrm{C}$, and then, the suspension was moved into $100 \mathrm{~mL}$ of MRS broth and stored at the same conditions. The system was centrifuged $(5 \mathrm{~min}$ at $10000 \times \mathrm{g}$ and $4^{\circ} \mathrm{C}$ ), and then the precipitate was collected and washed with sterilized saline to obtain the bacteria cells.

\subsection{Preparing Drying Carrier Media}

2.3.1. Preparing WPI and SPI Dispersions. Phosphate-buffer saline at $\mathrm{pH} 7.2$ containing sodium phosphate $(10 \mathrm{mM})$ and sodium chloride $(130 \mathrm{mM})$ was prepared, and tween $80(2 \%$, $\mathrm{w} / \mathrm{w})$ and glycerol $(2 \%, \mathrm{w} / \mathrm{w})$ were added to it and stirred for half an hour. Then, WPI or SPI was added to the solution at $20 \%(w / w)$ concentration and stirred for $12 \mathrm{~h}$.

2.3.2. Preparing $W P I+I N$ and $S P I+I N$ Dispersions. To make WPI4I/SPI4I dispersion, inulin was added to the buffer-phosphate saline containing $2 \%$ glycerol (as explained in Section 2.3.1) at $4 \%(\mathrm{w} / \mathrm{w})$ concentration and then heated for $1 \mathrm{~min}$ in a microwave. WPI/SPI was added to it at $20 \%$ $(\mathrm{w} / \mathrm{w})$ concentration and stirred for $12 \mathrm{~h}$.

2.4. Microencapsulation of the Probiotic Bacteria through Spray Drying. To prepare coats of WPI/WPI4I/SPI/SPI4I around the probiotic M.O, the bacteria cells (8 log CFU/g) were mixed with the wall material, and then, the mixture was dried using a spray drier (Maham Co., Iran) at the feeding rate of $500 \mathrm{~mL} / 60 \mathrm{~min}$. The inlet temperature was set on $100^{\circ} \mathrm{C}$, and the outlet temperature was $60^{\circ} \mathrm{C}$ with 2 bar nozzle pressure. The obtained powders were then kept in sealed containers at refrigerator temperature $\left(4^{\circ} \mathrm{C}\right)$.

2.4.1. Particle Size Distribution. To determine the particle size of the obtained powders after spray drying, each powder was dispersed in deionized distilled water, and the particle size was measured using laser diffraction (W3325, Microtrac, USA) [12].

2.4.2. Determining Cell Viability at Harsh Conditions. Encapsulated and free L. reuteri were subjected to the below harsh conditions, and then, the viability was determined through MRS agar method. After dilution of bacteria in saline, one $\mathrm{mL}$ of diluted solution was cultured on the MRS agar by pour plate method and incubated at $37^{\circ} \mathrm{C}$ for $48 \mathrm{~h}$.
(1) Effect of Heat. The spray dried powder was added to distilled water (at neutral $\mathrm{pH}$ ) at $1: 10$ mixing ratio in a tube and then heated for $0.5 \mathrm{~min}$ at 40,60 , and $80^{\circ} \mathrm{C}$ followed by rapid cooling in $4^{\circ} \mathrm{C}$ water. Then, the cell viability was determined as mentioned in 2.4.2 Section.

(2) Effect of $p H$. To determine the effect of acidic $\mathrm{pH}$ on the viability of the bacteria, $1 \mathrm{~g}$ of each type of the powders was added to $10 \mathrm{~mL}$ of DDW with $0.2 \% \mathrm{NaCl}$ at $\mathrm{pH} 1.5$ and 2.5 ( $\mathrm{pH}$ adjusted with $0.1 \mathrm{~N} \mathrm{HCl}$ ) and kept for $60 \mathrm{~min}$. Then, the cell viability was determined as mentioned [13].

(3) Effect of $\mathrm{NaCl}$. To investigate the viability of encapsulated probiotics against salt, subinhibitory concentrations of sodium chloride were chosen. MRS agar medium was prepared, and then, the coated M.Os were plated on the medium in the presence of $2 \%$ and $4 \%$ sodium chloride. The plates were kept in an incubator at $37^{\circ} \mathrm{C}$ for $60 \mathrm{~h}$. Unencapsulated bacteria plated on MRS agar medium in the absence of any salt were considered as the control sample [14].

(4) Effect of Bile Salt and Penicillin G on Cell Viability. Cell viability of the dried encapsulated probiotics against bile salt or penicillin $\mathrm{G}$ was examined as described by Golowczyc et al. [14] by adding bile salt at $1 \%(\mathrm{w} / \mathrm{v})$ concentration or penicillin $\mathrm{G}$ at $1 \mu \mathrm{g} / \mathrm{mL}$ concentration to the sterilized MRS agar medium. The chosen bile salt/penicillin G concentration was below the minimum inhibitory concentration. Then, the encapsulated M.Os were plated on the medium and incubated at $37^{\circ} \mathrm{C}$ for $60 \mathrm{~h}$.

2.4.3. Survival in Simulated Gastrointestinal Conditions. To examine the $L$. reuteri survival in its encapsulated form against simulated gastrointestinal condition, simulated gastric juice and intestinal juice (SGJ and SIJ, respectively) were prepared based on the method of Moayyedi et al. [15]. Briefly, for SGR, $\mathrm{NaCl}(0.9 \%$, w/v) and pepsin $(0.3 \%$, w/v) were added to DDW and stirred until dissolving, and then, $\mathrm{pH}$ was set on 1.5 using $\mathrm{HCl}$ solution $(1 \mathrm{~N})$. SIJ was prepared by addition of bile salt $(0.6 \%, \mathrm{w} / \mathrm{v})$ and pancreatin $(0.2 \%, \mathrm{w} / \mathrm{v})$ to $0.6 \% \mathrm{NaCl}$ solution and setting $\mathrm{pH}$ on 6 using $\mathrm{NaOH}$ solution $(1 \mathrm{~N})$. To sterilize the prepared SGJ and SIG, they were passed through $0.22 \mu \mathrm{m}$ filter. Then, $1 \mathrm{~g}$ of the encapsulated probiotics was added to $9 \mathrm{~mL}$ of SGJ/SIJ and shaken at $50 \mathrm{rpm}$ at $37^{\circ} \mathrm{C}$. After 1 and $2 \mathrm{~h}$, the samples were diluted and plated on MRS agar and incubated at $37^{\circ} \mathrm{C}$ for $60 \mathrm{~h}$. Then, the colonies were counted. The unencapsulated bacteria were tested at the same condition as the control sample.

2.4.4. Storage Stability. Samples were stored in a closed container containing supersaturated $\mathrm{LiCl}$ solution at $11 \%$ $\mathrm{RH}$ and ambient temperature for 12 weeks based on previous studies [16]. Survival of the probiotics under such condition was determined based on $\log \mathrm{N} / \mathrm{N}_{0}$, where $\mathrm{N}$ is the count of probiotics at a certain time during the storage period, and $\mathrm{N}_{0}$ is the probiotics count at the beginning of the experiment [16]. 
2.5. Statistical Analysis. All experiments were performed in triplicate unless otherwise indicated. The results were analyzed using one-way analysis of variance at the significance level of 0.05 . Duncan's multiple range tests $\left(\mathrm{SAS}^{\circledR}{ }^{\circledR}\right.$ software, ver. 9.1, SAS Institute Inc., NC, USA) were used to determine significant differences between the means.

\section{Result and Discussion}

3.1. Particle Size. Particle size of encapsulated bioactive materials influences their application in fortifying foods [17]. The results of particle size distribution of encapsulated L. reuteri bacteria (Figure 1) showed significant differences between samples. The particle size of the samples was in the range of 195.2-358.1 nm. Probiotics encapsulated within SPI showed the biggest size $(358.1 \mathrm{~nm})$, and those within SPI4I and WPI were in the next orders with the sizes of $313.3 \mathrm{~nm}$ and $284.1 \mathrm{~nm}$. The smallest particle size was related to WPI4I sample $(195.2 \mathrm{~nm})$. The observed differences can be attributed to different film forming and gelling ability of the wall materials. In another work by López-Rubio et al. [18], different mixtures of wall materials including pullulan, milk powder, and WPC + milk powder were used to encapsulate Bifidobacterium through electrospraying. They reported that the particle size of the encapsulated probiotic was in the range of $295-658 \mathrm{~nm}$.

3.2. Effect of Heat on Viability. Heat shock is one of the main stresses on bacteria that can decrease their viability. The unencapsulated and encapsulated $L$. reuteri bacteria within different types of wall materials were exposed to different temperatures $\left(40,60\right.$, and $\left.80^{\circ} \mathrm{C}\right)$, and the result of their viability is reported in Figure 2. As can be seen, different temperatures and wall materials showed different effects on the viability of the probiotics. For unencapsulated bacteria, their count decreased from $8.08 \log$ at the beginning of the experiment to $8.04 \log$ and $5.81 \log$ after heating at $40^{\circ} \mathrm{C}$ and $60^{\circ} \mathrm{C}$, respectively. Due to the high sensitivity of the free form to heat, it could not survive at $80^{\circ} \mathrm{C}$. For the probiotics encapsulated within WPI4I, treating at $40^{\circ} \mathrm{C}$ resulted in an increase in the bacterial count from $8.13 \log \mathrm{CFU} / \mathrm{mL}$ to $8.18 \log \mathrm{CFU} / \mathrm{mL}$, while treating at $60^{\circ} \mathrm{C}$ and $80^{\circ} \mathrm{C}$ significantly decreased it to $8.09 \log \mathrm{CFU} / \mathrm{mL}$ and $7.31 \log \mathrm{CFU} /$ $\mathrm{mL}$, respectively. The number of M.O encapsulated within SPI remained constant after heating at $40^{\circ} \mathrm{C}(8.15 \log \mathrm{CFU} /$ $\mathrm{mL}$ ), while it reduced to $7.98 \log \mathrm{CFU} / \mathrm{mL}$ and $7.12 \log \mathrm{CFU} /$ $\mathrm{mL}$ at $60^{\circ} \mathrm{C}$ and $80^{\circ} \mathrm{C}$, respectively. For the probiotics encapsulated within SPI4I and WPI, heating resulted (at 60 and $80^{\circ} \mathrm{C}$ ) in a decrease in the bacterial count (from $8.16 \log$ $\mathrm{CFU} / \mathrm{mL}$ and $8.14 \log \mathrm{CFU} / \mathrm{mL}$, respectively). Higher temperatures resulted in higher decrease, so that the minimum counts were observed after heating at $80^{\circ} \mathrm{C}(7.24 \log \mathrm{CFU} /$ $\mathrm{mL}$ for the SPI4I sample and $7.18 \log \mathrm{CFU} / \mathrm{mL}$ for the WPI sample). Similar to our result, Kim et al. [19] showed that $L$. acidophilus still survive at $53^{\circ} \mathrm{C}$, while surviving was stopped at $60^{\circ} \mathrm{C}$. In another study done by Mandal et al. [10], it was shown that heating at 55,60 , and $65^{\circ} \mathrm{C}$ was lethal for unencapsulated bacteria, while encapsulated bacteria survived.
3.3. Effect of pH on Viability. Efficiency and health promoting effects of probiotic bacteria in the human body are dependent on their viability in the gastrointestinal tract (GI). The $\mathrm{pH}$ of GI is one of the important factors that threaten the viability of probiotics. In this research, the viability of unencapsulated and microencapsulated $L$. reuteri was examined at simulated gastric $\mathrm{pH}$ of $1.5,2.5$, and 7 , and the obtained results are represented in Figure 3. As can be seen, the viability of the organisms decreased by decreasing the $\mathrm{pH}$ value, so that the maximum count of $L$. reuteri was observed at $\mathrm{pH} 7$ for all samples $(8.10 \log \mathrm{CFU} / \mathrm{mL}$ for SPI, $8.13 \log$ $\mathrm{CFU} / \mathrm{mL}$ for SPI4I, $8.14 \log \mathrm{CFU} / \mathrm{mL}$ for WPI, $8.10 \log \mathrm{CFU} /$ $\mathrm{mL}$ for WPI4I, and $8.11 \log \mathrm{CFU} / \mathrm{mL}$ for the free sample), and the minimum was observed at $\mathrm{pH} 1.5(6.02 \mathrm{log} \mathrm{CFU} / \mathrm{mL}$ for SPI, $6.07 \log \mathrm{CFU} / \mathrm{mL}$ for SPI4I, $6.06 \log \mathrm{CFU} / \mathrm{mL}$ for WPI, $6.14 \log \mathrm{CFU} / \mathrm{mL}$ for WPI4I, and $4.10 \log \mathrm{CFU} / \mathrm{mL}$ for the free sample). It was also revealed that the viability of the probiotic bacteria in their free form was significantly $(p \leq 0.05)$ lower than that of the encapsulated form at the acidic $\mathrm{pH}$ values of 1.5 and 2.5 , which shows the efficient role of the wall materials on protecting $L$. reuteri against GI $\mathrm{pH}$. Similar results were reported by others. Chandramouli et al. [20] showed that encapsulation of Lactobacillus acidophilus within alginate bead enhanced their viability at $\mathrm{pH} 2$ considerably. Krasaekoopt et al. [21] showed higher survival for $L$. acidophilus in gastric juice after encapsulation within alginate. Similarly, Afzaal et al. [22] introduced encapsulation as a method to enhance the viability of probiotics in the acidic condition of GI. In other researches, it was approved that encapsulation of probiotic microorganism is an efficient way to increase their viability in fermented acidic products such as yoghurt $[23,24]$.

3.4. Effect of NaClon Viability. Figure 4 indicates the effect of different salt concentrations $(0,2$, and $4 \%)$ on the viability of free and different types of encapsulated L. reuteri. As expected, the highest $\mathrm{NaCl}$ concentration (4\%) resulted in reduction in the bacterial count in all samples. Comparison between different samples showed the maximum count reduction in the control sample $(2.45 \log \mathrm{CFU} / \mathrm{mL})$ and the minimum count reduction in the sample encapsulated within $\mathrm{WPT}+\mathrm{IN}(0.11 \log \mathrm{CFU} / \mathrm{mL})$. This observation shows the efficient role of this wall material on the viability. Sodium chloride at $2 \%$ concentration had no significant effect on the cell survival in the sample encapsulated within SPI, while it increased the cell counts for those encapsulated within SPI4I, WPI, and WPI4I. The control sample was the only sample that its count was decreased in the presence of $2 \% \mathrm{NaCl}$, which shows the high sensitivity of unencapsulated $L$. reuteri to the salt. Similar results on the viability of probiotic bacteria were reported by Martín et al. [25], Peighambardoust et al. [26], Mohammadi-Gouraji et al. [27]. Golowczyc et al. [28].

3.5. Effect of Bile Salt on Viability. Bile salt that is found in abundance in the GI can have lethal effect on probiotics and reduce their count. In this test, the effects of bile salt at $1 \%$ concentration on the survival of encapsulated $L$. reuteri were 


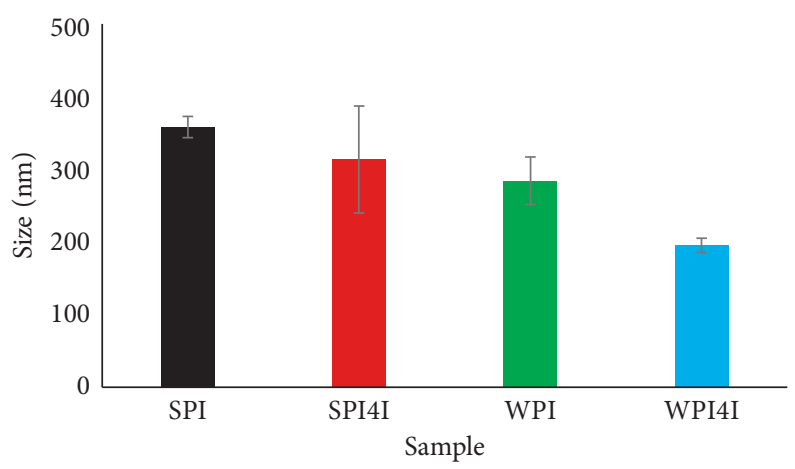

(a)
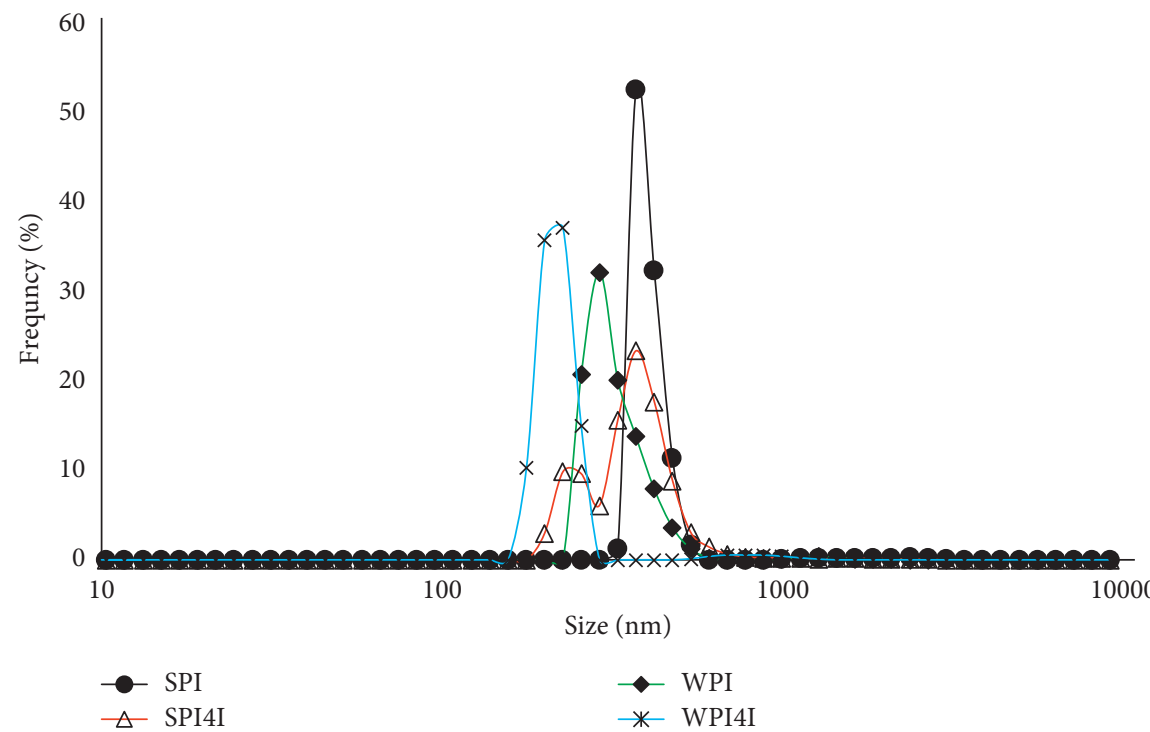

Size $(\mathrm{nm})$

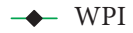

* WPI4I

(b)

Figure 1: Particle size (a) and size distribution (b) of encapsulated L. reuteri bacteria; SPI: soy protein isolate 20\%, SPI4I: soy protein isolate $20 \%+$ inulin $4 \%$, WPI: whey protein isolate $20 \%$, WPI 4 I: whey protein isolate $20 \%+$ inulin $4 \%$.

investigated, and the results are shown in Figure 5. Comparing the viability of the control (free) and encapsulated probiotics in the absence $(0 \%)$ and presence $(1 \%)$ of bile salt showed that bile salt decreased significantly $(p \leq 0.05)$ the viability of the both types (free and encapsulated) of L. reuteri. In addition, it was observed the survival of the control sample was much lower than others (8.68 log CFU/ $\mathrm{mL}$ in $0 \%$ bile salt and $6.41 \log \mathrm{CFU} / \mathrm{mL}$ in $1 \%$ bile salt). This result showed the protective role of the wall materials against bile salt. The strongest protective effect was related to WPI + IN as the bacterial count decreased only $0.24 \mathrm{log}$ $\mathrm{CFU} / \mathrm{mL}$, and the weakest protective effect was related to SPI with $0.5 \log \mathrm{CFU} / \mathrm{mL}$ reduction. Similar results were reported by Lee and Heo [29] and Krasaekoopt et al. [21]. Hernández-Gómez et al. [30] and Chen et al. [31] indicated that encapsulation can prevent the probiotic count reduction in the GI in the presence of bile salt. Some researchers that investigated the survival of lactic acid bacteria in the presence of bile salt emphasized that the bile-tolerant strains of probiotics that are planned to be used in the foods should be identified $[32,33]$. The protective impacts of maize starch and alginate on probiotics against different concentrations of bile salt have been reported in another study [20]. In contrast to these results, some researches showed that some types of wall materials were not effective in this regard. For example, Trindade and Grosso [34] showed that calcium alginate beads did not protect Bifidobacterium bifidum and L. acidophilus against different concentrations of bile salts. Higher reduction of probiotics count after encapsulated within protein-polysaccharide beads was also reported by Guérin et al. [35].

3.6. Effect of Penicillin on Viability. As penicillin has a lethal effect on probiotics, its presence in the intestine can threaten the survival of probiotics [15]. So, we examined how the presence of different types of microcapsules can protect L. reuteri against penicillin at $1 \%$ concentration. Free bacteria were used as the control sample. Based on Figure 6 that shows the results, the effect of penicillin on the probiotic survival was similar to that of $\mathrm{NaCl}$ at $4 \%$ concentration and bile salt. Viability of all samples decreased significantly $(p \leq 0.05)$ after exposure to penicillin, and the maximum reduction in the bacterial count was observed for the control sample $(4.24 \log \mathrm{CFU} / \mathrm{mL})$. The highest and lowest 


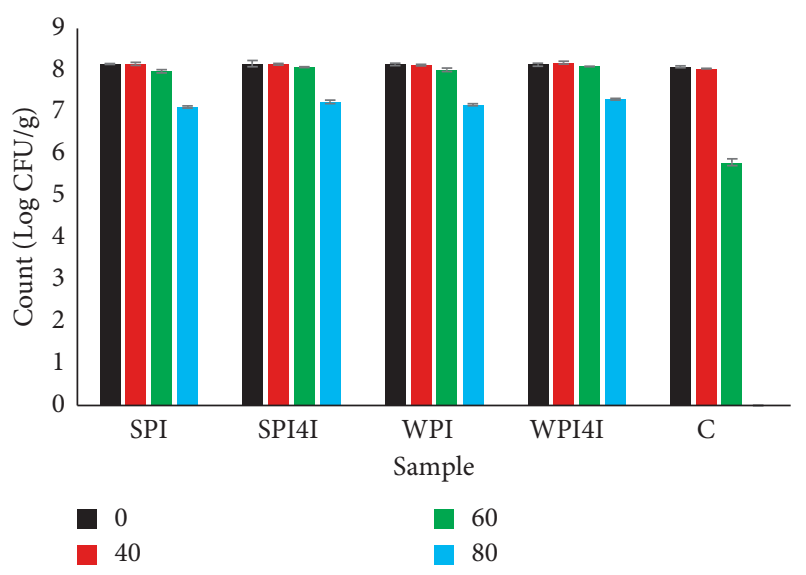

Figure 2: Effect of heating $\left(0,40,60\right.$, and $\left.80^{\circ} \mathrm{C}\right)$ on the viability of L. reuteri encapsulated within different wall materials (SPI: soy protein isolate $20 \%$, SPI4I: soy protein isolate $20 \%+$ inulin $4 \%$, WPI: whey protein isolate $20 \%$, WPI4I: whey protein isolate $20 \%+$ inulin $4 \%$, C: free bacteria).

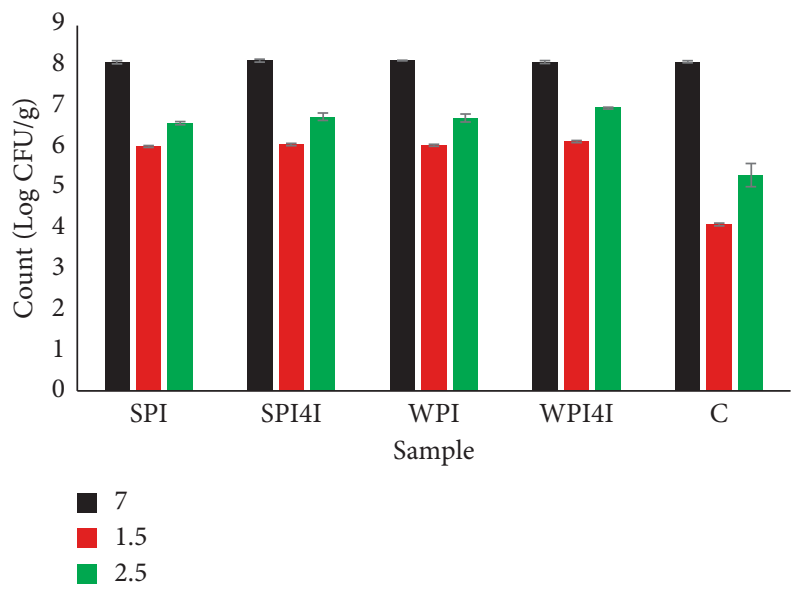

Figure 3: Effect of $\mathrm{pH}(7,1.5,2.5)$ on the viability of $L$. reuteri encapsulated within different wall materials; SPI (soy protein isolate 20\%), SPI4I (soy protein isolate $20 \%+$ inulin $4 \%$ ), WPI (whey protein isolate 20\%), WPI4I (whey protein isolate $20 \%+$ inulin $4 \%$ ), and C (free bacteria).

protective effects of the wall materials were related to WPI4I $(1.29 \log \mathrm{CFU} / \mathrm{mL})$ and SPI $(1.54 \log \mathrm{CFU} / \mathrm{mL})$, respectively. Similar results were reported by Moayyedi, Eskandari, Rad, Ziaee, Khodaparast and Golmakani [15].

\subsection{Viability in Simulated Gastric and Intestinal Condition.}

To determine the viability of the encapsulated and free L. reuteri in the gastrointestinal tract condition, samples were incubated for $60 \mathrm{~min}$ and $120 \mathrm{~min}$ in the simulated gastric and intestinal juices, and their viability was reported as $\log \mathrm{CFU} / \mathrm{mL}$ in Figures 7 and 8 . The results showed that, in the gastric condition, the presence of the microcapsules as well as the microcapsules type caused significant $(p \leq 0.05)$ effects on the cells viability. In all samples, increasing the incubation time led to decrease the probiotic count. The control samples showed the maximum reduction, so that its count decreased from $9.20 \mathrm{log}$
$\mathrm{CFU} / \mathrm{mL}$ to $7.21 \log \mathrm{CFU} / \mathrm{mL}$ and $5.40 \log \mathrm{CFU} / \mathrm{mL}$ after $60 \mathrm{~min}$ and $120 \mathrm{~min}$, respectively. The highest protective effect on survival of the probiotic was related to the samples encapsulated within SPI4I as its initial count $(9.15 \log \mathrm{CFU} / \mathrm{mL})$ decreased to $8.38 \log \mathrm{CFU} / \mathrm{mL}$ after $60 \mathrm{~min}$ and $8.34 \log \mathrm{CFU} /$ $\mathrm{mL}$ after $120 \mathrm{~min}$. In simulated intestine juice, count reduction was less than the simulated gastric juice. Similar to the gastric condition, free bacteria (control sample) showed the highest sensitivity to the intestinal condition as it had $0.83 \log \mathrm{CFU} / \mathrm{mL}$ and $2.07 \log \mathrm{CFU} / \mathrm{mL}$ reduction after $60 \mathrm{~min}$ and $120 \mathrm{~min}$, respectively. The best protective impact was observed for WPI4I sample. It means that the combination of WPI and inulin protected the probiotic bacteria more effectively. In agreement to our results, Coghetto et al. [36] declared that when they examined the viability of L. plantarum BL011 encapsulated within sodium alginate/sodium alginate-citric pectin through electrospraying in the simulated intestinal juice, they observed the protective effect of the wall material on the survival of the bacteria ( $4.02 \log \mathrm{CFU} / \mathrm{mL}$ reduction for the control sample and $2.07 \log \mathrm{CFU} / \mathrm{mL}$ reduction for the encapsulated type). Investigating the survival of $L$. reuteri by a dynamic model of the bacterial filtration method and gastrointestinal tract can be valuable to do in our future research.

3.8. Storage Stability. Figure 9 shows the effect of microcapsules type on the viability of different encapsulated $L$. reuteri probiotic at $25^{\circ} \mathrm{C}$ during 90 days at 15 days intervals. Reduction in the bacterial count in all samples was more noticeable after 30 days. Decreasing the bacterial count during the storage period occurs mostly due to oxidation of lipids presented in the cell membrane [15]. So, the parameters that affect the lipid oxidation rate and extend such as moisture content and temperature should be controlled during storage [37]. The minimum and maximum bacterial count at the end of the storage period were related to the probiotics encapsulated within SPI (8.94 $\log \mathrm{CFU} / \mathrm{mL})$ and those encapsulated within WPI4I (9.24 $\log \mathrm{CFU} / \mathrm{mL})$, respectively. It indicates the higher efficiency of WPI + IN in protection of $L$. reuteri against membrane lipid oxidation. In a research, different types of wall materials including zein, WPC, Fibersol, maltodextrin, and PVP were used to encapsulate probiotic bacteria using electrospraying method. It was observed that, after 600 days of storage, the count of all of the encapsulated bacteria was higher than $4 \log \mathrm{CFU} / \mathrm{g}$. The strongest and weakest protective effects were related to WPC and maltodextrin, respectively [38]. Based on the report of Hoobin et al. [39], adding inulin to WPI as a wall material increased the cell viability during the storage period. They also mentioned molecular mobility and moisture content as important parameters affecting cell survival during storage period. Perez-Gago and Krochta [40] observed that carbohydrate could protect the cells better than WPI wall material because of its low permeability to oxygen and moisture. LópezRubio et al. [18] compared two methods of encapsulation of Bifidobacterium on their survival during storage. They observed higher viability for samples encapsulated through electrospraying compared to freeze drying as the bacterial count reached 0 after 80 days in freeze drying method, while it was higher than $7 \log \mathrm{CFU} / \mathrm{mL}$ after 100 days in electrospraying method. 


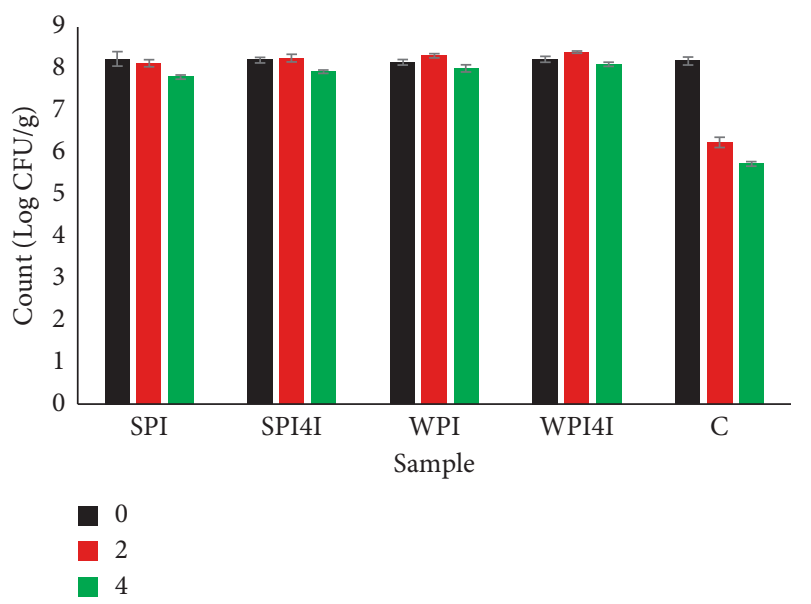

FIGURE 4: Effect of $\mathrm{NaCl}(0,2$ and 4\%) on the viability of L. reuteri encapsulated within different wall materials; SPI (soy protein isolate 20\%), SPI4I (soy protein isolate $20 \%+$ inulin $4 \%$ ), WPI (whey protein isolate $20 \%$ ), WPI4I (whey protein isolate $20 \%+$ inulin $4 \%$ ), and C (free bacteria).

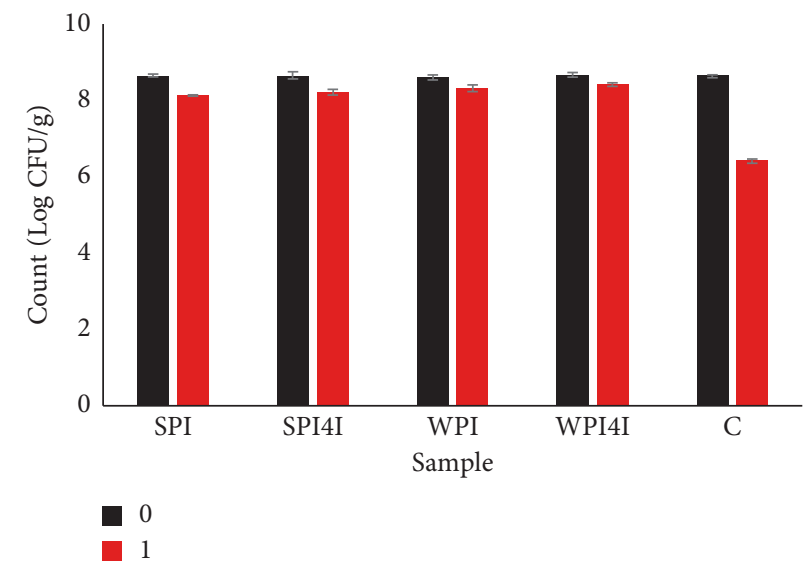

FIGURE 5: Effect of bile salt ( 0 and $1 \%$ ) on the viability of $L$. reuteri encapsulated within different wall materials; SPI (soy protein isolate $20 \%$ ), SPI4I (soy protein isolate $20 \%+$ inulin $4 \%$ ), WPI (whey protein isolate $20 \%$ ), WPI4I (whey protein isolate $20 \%+$ inulin $4 \%$ ), and C (free bacteria).

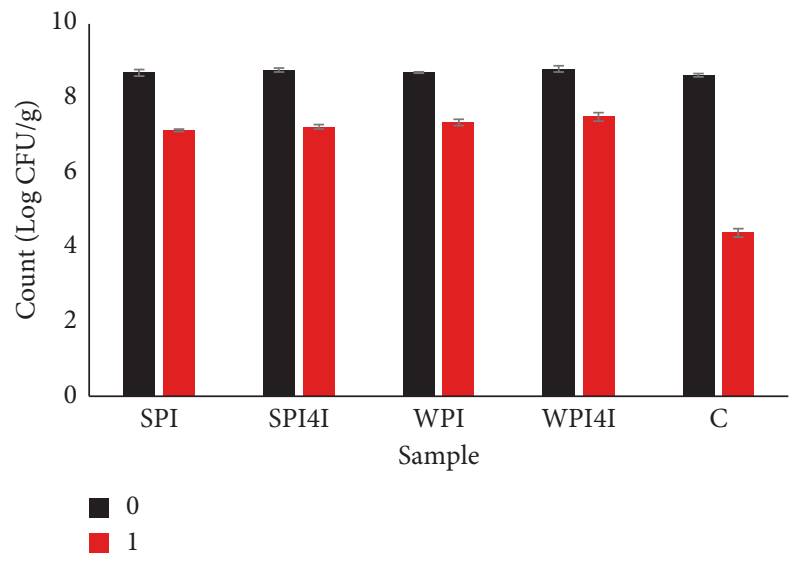

FIGURE 6: Effect of penicillin ( 0 and $1 \mu \mathrm{g} / \mathrm{mL})$ on the viability of L. reuteri encapsulated within different wall materials; SPI (soy protein isolate $20 \%$ ), SPI4I (soy protein isolate $20 \%+$ inulin $4 \%$ ), WPI (whey protein isolate $20 \%$ ), WPI 4 I (whey protein isolate $20 \%+$ inulin $4 \%$ ), and $\mathrm{C}$ (free bacteria). 


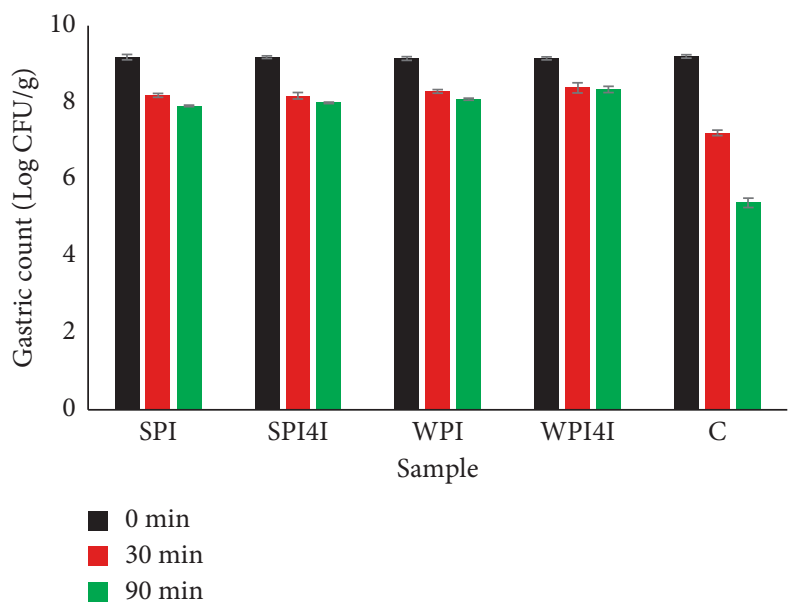

FIGURE 7: Viability of $L$. reuteri encapsulated within different wall materials in gastric condition; SPI (soy protein isolate 20\%), SPI4I (soy protein isolate $20 \%+$ inulin $4 \%$ ), WPI (whey protein isolate $20 \%$ ), WPI4I (whey protein isolate $20 \%+$ inulin $4 \%$ ), and C (free bacteria).

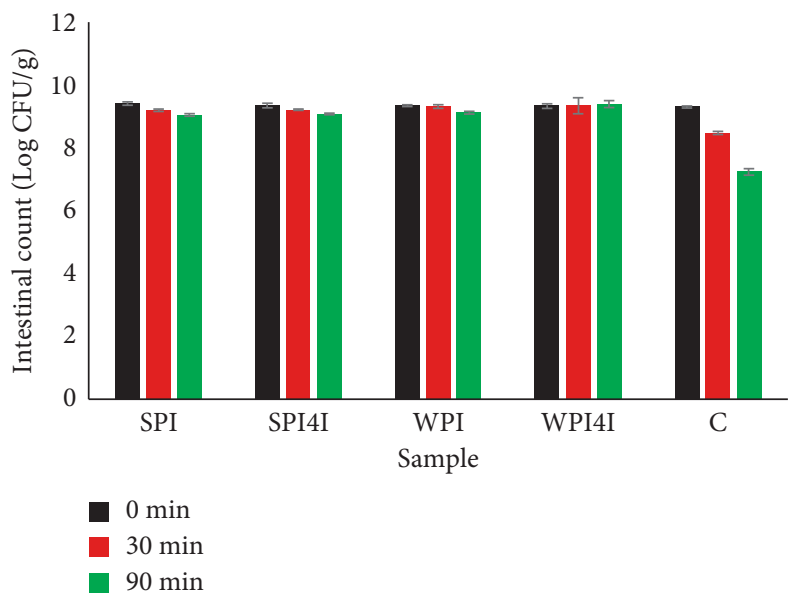

FIGURE 8: Viability of L. reuteri encapsulated within different wall materials in intestinal condition; SPI (soy protein isolate 20\%), SPI4I (soy protein isolate $20 \%+$ inulin $4 \%$ ), WPI (whey protein isolate $20 \%$ ), WPI4I (whey protein isolate $20 \%+$ inulin $4 \%$ ), and C (free bacteria).

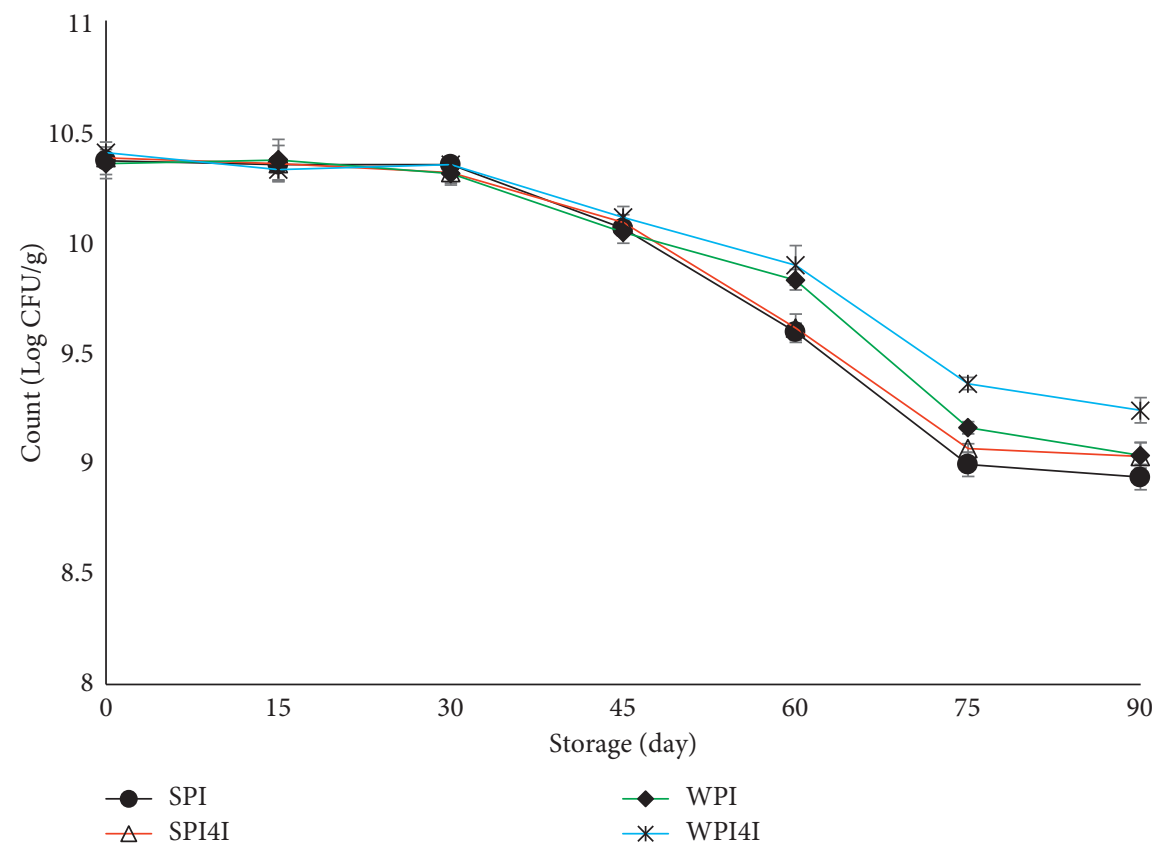

FIGURE 9: Viability of L. reuteri encapsulated within different wall materials during storage; SPI (soy protein isolate 20\%), SPI4I (soy protein isolate $20 \%+$ inulin $4 \%$ ), WPI (whey protein isolate $20 \%$ ), WPI4I (whey protein isolate $20 \%+$ inulin $4 \%$ ), and C (free bacteria). 


\section{Conclusion}

In this research, $L$. reuteri probiotic bacteria were encapsulated within different wall materials including SPI, SPI + IN, WPI, and WPI + IN through spray drying method. Particle size of the prepared samples was below $360 \mathrm{~nm}$. The viability of the samples was examined in harsh conditions including heat treatment, acidic $\mathrm{pH}$ values, and simulated gastrointestinal juice, and in the presence of $\mathrm{NaCl}$, bile salt, and penicillin, as well as during storage period, and then, the results were compared with the viability of unencapsulated probiotic sample at the same conditions. It was observed that increasing the temperature and $\mathrm{NaCl}$ concentration decreased the viability of the probiotics. Bile salt and penicillin had lethal effect on the probiotics. In acidic condition (SGJ), the reduction of cell count was more obvious than neutral condition (SIC). The rate of reduction in the cell counts increased after 1 month of storage. In all samples, viability of encapsulated bacteria was much higher than viability of unencapsulated bacteria, which shows the important role of different types of microcapsules on protection of the cells. In addition, WPI4I had the strongest protective role as compared to the other wall materials.

\section{Data Availability}

The data used to support this study are available from the corresponding author upon request.

\section{Conflicts of Interest}

The authors declare that they have no conflicts of interest.

\section{Acknowledgments}

This research was funded by Islamic Azad University of Kazeroon under the Grant no. GN950315167.

\section{References}

[1] F. Zendeboodi, N. Khorshidian, A. M. Mortazavian, and A. G. da Cruz, "Probiotic: conceptualization from a new approach," Current Opinion in Food Science, vol. 32, pp. 103-123, 2020.

[2] C. Maldonado Galdeano, S. I. Cazorla, J. M. Lemme Dumit, E. Vélez, and G. Perdigón, "Beneficial effects of probiotic consumption on the immune system," Annals of Nutrition and Metabolism, vol. 74, no. 2, pp. 115-124, 2019.

[3] P. Tanganurat, "Probiotics encapsulated fruit juice bubbles as functional food product," Cell, vol. 4, no. 5, 2020.

[4] M. Zeashan, M. Afzaal, F. Saeed et al., "Survival and behavior of free and encapsulated probiotic bacteria under simulated human gastrointestinal and technological conditions," Food Sciences and Nutrition, vol. 8, no. 5, pp. 2419-2426, 2020.

[5] A. A. Boricha, S. L. Shekh, S. P. Pithva, P. S. Ambalam, and B. R. Manuel Vyas, "In vitro evaluation of probiotic properties of Lactobacillus species of food and human origin," LebensmittelWissenschaft und -Technologie, vol. 106, pp. 201-208, 2019.

[6] B. A. Akweya, J. M. Mghalu, R. U. M. Yusuf, and T. Bitange, "Probiotic potential of lactic acid bacteria isolated from traditionally fermented legume products of Western Kenya," African Journal of Food Science, vol. 14, pp. 373-377, 2020.
[7] M. Mbye, M. A. Baig, S. F. AbuQamar et al., "Updates on understanding of probiotic lactic acid bacteria responses to environmental stresses and highlights on proteomic analyses," Comprehensive Reviews in Food Science and Food Safety, vol. 19, no. 3, pp. 1110-1124, 2020.

[8] Y. Shin, C.-H. Kang, W. Kim, and J.-S. So, "Heat adaptation improved cell viability of probiotic Enterococcus faecium HL7 upon various environmental stresses," Probiotics and antimicrobial proteins, vol. 11, no. 2, pp. 618-626, 2019.

[9] M. A. O. Dawood, S. Koshio, M. M. Abdel-Daim, and H. Van Doan, "Probiotic application for sustainable aquaculture," Reviews in Aquaculture, vol. 11, no. 3, pp. 907-924, 2019.

[10] S. Mandal, A. K. Puniya, and K. Singh, "Effect of alginate concentrations on survival of microencapsulated Lactobacillus casei NCDC-298," International Dairy Journal, vol. 16, no. 10, pp. 1190-1195, 2006.

[11] W. K. Ding and N. P. Shah, "Acid, bile, and heat tolerance of free and microencapsulated probiotic bacteria," Journal of Food Science, vol. 72, no. 9, pp. M446-M450, 2007.

[12] H. H. Gahruie, M. H. Eskandari, M. Khalesi, P. Van der Meeren, and S. M. H. Hosseini, "Rheological and interfacial properties of basil seed gum modified with octenyl succinic anhydride," Food Hydrocolloids, vol. 101, Article ID 105489, 2020.

[13] L. Sabikhi, R. Babu, D. K. Thompkinson, and S. Kapila, "Resistance of microencapsulated Lactobacillus acidophilus LA1 to processing treatments and simulated gut conditions," Food and Bioprocess Technology, vol. 3, no. 4, pp. 586-593, 2010.

[14] M. A. Golowczyc, C. L. Gerez, J. Silva, A. G. Abraham, G. L. De Antoni, and P. Teixeira, "Survival of spray-dried Lactobacillus kefir is affected by different protectants and storage conditions," Biotechnology Letters, vol. 33, no. 4, pp. 681-686, 2011.

[15] M. Moayyedi, M. H. Eskandari, A. H. E. Rad, E. Ziaee, M. H. H. Khodaparast, and M.-T. Golmakani, "Effect of drying methods (electrospraying, freeze drying and spray drying) on survival and viability of microencapsulated Lactobacillus rhamnosus ATCC 7469," Journal of functional foods, vol. 40, pp. 391-399, 2018.

[16] E. O. Sunny-Roberts and D. Knorr, "The protective effect of monosodium glutamate on survival of Lactobacillus rhamnosus GG and Lactobacillus rhamnosus E-97800 (E800) strains during spray-drying and storage in trehalose-containing powders," International Dairy Journal, vol. 19, no. 4, pp. 209-214, 2009.

[17] R. Rajam and C. Anandharamakrishnan, "Microencapsulation of Lactobacillus plantarum (MTCC 5422) with fructooligosaccharide as wall material by spray drying," Lebensmittel-Wissenschaft und-Technologie-Food Science and Technology, vol. 60, no. 2, pp. 773-780, 2015.

[18] A. López-Rubio, E. Sanchez, S. Wilkanowicz, Y. Sanz, and J. M. Lagaron, "Electrospinning as a useful technique for the encapsulation of living bifidobacteria in food hydrocolloids," Food Hydrocolloids, vol. 28, no. 1, pp. 159-167, 2012.

[19] W. S. Kim, L. Perl, J. H. Park, J. E. Tandianus, and N. W. Dunn, "Assessment of stress response of the probiotic Lactobacillus acidophilus," Current Microbiology, vol. 43, no. 5, pp. 346-350, 2001.

[20] V. Chandramouli, K. Kailasapathy, P. Peiris, and M. Jones, "An improved method of microencapsulation and its evaluation to protect Lactobacillus spp. in simulated gastric 
conditions," Journal of Microbiological Methods, vol. 56, no. 1, pp. 27-35, 2004.

[21] W. Krasaekoopt, B. Bhandari, and H. Deeth, "The influence of coating materials on some properties of alginate beads and survivability of microencapsulated probiotic bacteria," International Dairy Journal, vol. 14, no. 8, pp. 737-743, 2004.

[22] M. Afzaal, F. Saeed, M. U. Arshad, M. T. Nadeem, M. Saeed, and T. Tufail, "The effect of encapsulation on the stability of probiotic bacteria in ice cream and simulated gastrointestinal conditions," Probiotics and antimicrobial proteins, vol. 11, no. 4, pp. 1348-1354, 2019.

[23] M. Afzaal, A. U. Khan, F. Saeed et al., "Functional exploration of free and encapsulated probiotic bacteria in yogurt and simulated gastrointestinal conditions," Food Sciences and Nutrition, vol. 7, no. 12, pp. 3931-3940, 2019.

[24] E. M. Kia, Z. Ghasempour, S. Ghanbari, R. Pirmohammadi, and A. Ehsani, "Development of probiotic yogurt by incorporation of milk protein concentrate (MPC) and microencapsulated Lactobacillus paracasei in gellan-caseinate mixture," British Food Journal, vol. 120, no. 7, pp. 1516-1528, 2018.

[25] M. J. Martín, F. Lara-Villoslada, M. A. Ruiz, and M. E. Morales, "Microencapsulation of bacteria: a review of different technologies and their impact on the probiotic effects," Innovative Food Science \& Emerging Technologies, vol. 27, pp. 15-25, 2015.

[26] S. H. Peighambardoust, A. Golshan Tafti, and J. Hesari, "Application of spray drying for preservation of lactic acid starter cultures: a review," Trends in Food Science \& Technology, vol. 22, no. 5, pp. 215-224, 2011.

[27] E. Mohammadi-Gouraji, M. Sheikh-Zeinoddin, and S. Soleimanian-Zad, "Effects of Persian gum and gum Arabic on the survival of Lactobacillus plantarum PTCC 1896, Escherichia coli, Xanthomonas axonopodis, and Saccharomyces cerevisiae during freeze drying," British Food Journal, vol. 119, no. 2, pp. 331-341, 2017.

[28] M. A. Golowczyc, J. Silva, P. Teixeira, G. L. De Antoni, and A. G. Abraham, "Cellular injuries of spray-dried Lactobacillus spp. isolated from kefir and their impact on probiotic properties," International Journal of Food Microbiology, vol. 144, no. 3, pp. 556-560, 2011.

[29] K.-Y. Lee and T.-R. Heo, "Survival of Bifidobacterium longum immobilized in calcium alginate beads in simulated gastric juices and bile salt solution," Applied and Environmental Microbiology, vol. 66, no. 2, pp. 869-873, 2000.

[30] J. G. Hernández-Gómez, A. López-Bonilla, G. Trejo-Tapia, S. V. Ávila-Reyes, A. R. Jiménez-Aparicio, and H. HernándezSánchez, "In vitro bile salt hydrolase (BSH) Activity screening of different probiotic microorganisms," Foods (Basel, Switzerland), vol. 10, p. 674, 2021.

[31] M.-J. Chen, H.-Y. Tang, and M.-L. Chiang, "Effects of heat, cold, acid and bile salt adaptations on the stress tolerance and protein expression of kefir-isolated probiotic Lactobacillus kefiranofaciens M1," Food Microbiology, vol. 66, pp. 20-27, 2017.

[32] T. Allain, S. Chaouch, M. Thomas et al., "Bile-salt-hydrolases from the probiotic strain Lactobacillus johnsonii La1 mediate anti-giardial activity in vitro and in vivo," Frontiers in $\mathrm{Mi}$ crobiology, vol. 8, p. 2707, 2018.

[33] N. Singhal, A. K. Maurya, S. Mohanty, M. Kumar, and J. S. Virdi, "Evaluation of bile salt hydrolases, cholesterollowering capabilities, and probiotic potential of Enterococcus faecium isolated from rhizosphere," Frontiers in Microbiology, vol. 10, p. 1567, 2019.
[34] C. F. Trindade and C. Grosso, "The effect of the immobilisation of Lactobacillus acidophilus and Bifidobacterium lactis in alginate on their tolerance to gastrointestinal secretions," Milchwissenschaft, vol. 55, pp. 496-499, 2000.

[35] D. Guérin, J.-C. Vuillemard, and M. Subirade, "Protection of bifidobacteria encapsulated in polysaccharide-protein gel beads against gastric juice and bile," Journal of Food Protection, vol. 66, no. 11, pp. 2076-2084, 2003.

[36] C. C. Coghetto, G. B. Brinques, N. M. Siqueira, J. Pletsch, R. M. D. Soares, and M. A. Z. Ayub, "Electrospraying microencapsulation of Lactobacillus plantarum enhances cell viability under refrigeration storage and simulated gastric and intestinal fluids," Journal of Functional Foods, vol. 24, pp. 316-326, 2016.

[37] C. Santivarangkna, U. Kulozik, and P. Foerst, "Inactivation mechanisms of lactic acid starter cultures preserved by drying processes," Journal of Applied Microbiology, vol. 105, no. 1, pp. 1-13, 2008.

[38] C. M. Librán, S. Castro, and J. M. Lagaron, "Encapsulation by electrospray coating atomization of probiotic strains," Innovative Food Science \& Emerging Technologies, vol. 39, pp. 216-222, 2017.

[39] P. Hoobin, I. Burgar, S. Zhu, D. Ying, L. Sanguansri, and M. A. Augustin, "Water sorption properties, molecular mobility and probiotic survival in freeze dried protein-carbohydrate matrices," Food \& Function, vol. 4, no. 9, pp. 1376-1386, 2013.

[40] M. Perez-Gago and J. Krochta, "Denaturation time and temperature effects on solubility, tensile properties, and oxygen permeability of whey protein edible films," Journal of Food Science, vol. 66, pp. 705-710, 2001. 